This article was downloaded by: [130.132.123.28]

On: 04 July 2015, At: 17:02

Publisher: Taylor \& Francis

Informa Ltd Registered in England and Wales

Registered Number: 1072954 Registered office: 5 Howick Place, London, SW1P IWG

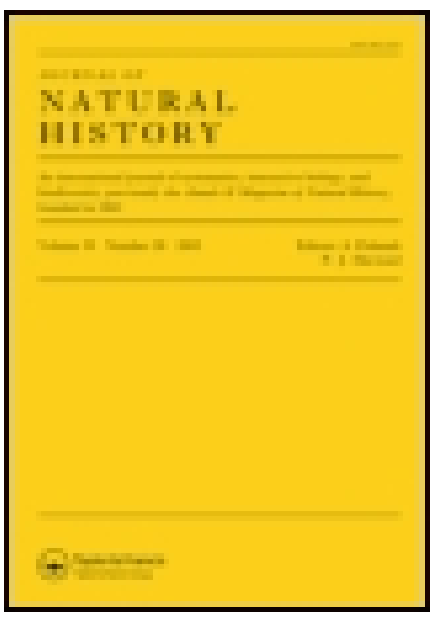

Annals and Magazine of Natural History: Series 1

Publication details, including instructions for authors and subscription information:

http://

www.tandfonline.com/loi/ tnah07

\title{
XXXVII. -On the Corymorpha nutans of Sars, a remarkable Hydroid polype
}

Edward Forbes Esq. \& J ohn Goodsir Esq.

Published online: $15 \mathrm{Mar}$ 2010.

To cite this article: Edward Forbes Esq. \& J ohn Goodsir Esq. (1840) XXXVII. - On the Corymorpha nutans of Sars, a remarkable Hydroid polype, Annals and Magazine of Natural History: Series 1, 5:32, 309-315, DOI: 10.1080/00222934009496835 


\section{PLEASE SCROLL DOWN FOR ARTICLE}

Taylor \& Francis makes every effort to ensure the accuracy of all the information (the "Content") contained in the publications on our platform. However, Taylor \& Francis, our agents, and our licensors make no representations or warranties whatsoever as to the $\therefore$ accuracy, completeness, or suitability for any purpose of the Content. Any opinions and views expressed in this publication are the opinions and views of the authors, and are not the views of or endorsed by Taylor $\&$ Francis. The accuracy of the Content should not be relied upon and should be independently verified with primary sources of information. Taylor and Francis shall not be liable for any losses, actions, claims, proceedings, demands, costs, expenses, damages, and other liabilities whatsoever or howsoever caused arising directly or indirectly in connection with, in relation to or arising out of the use of the Content.

This article may be used for research, teaching, and private study purposes. Any substantial or systematic reproduction, redistribution, reselling, loan, sublicensing, systematic supply, or distribution in any form to anyone is expressly forbidden. Terms \& Conditions of access and use can be found at http:// www.tandfonline.com/page/terms-and-conditions 
two sharp denticles at the tip, and the inner edge of the curved part minutely serrulated. Spines yellow, tapered insensibly to a rather obtuse point, one to each brush of bristles. Tentacular cirri awl-shaped, abruptly acuminate, downy or ciliate, of a dusky or dark colour, with paler spots, reaching to or a little beyond the apex of the foot; all the feet posterior to the 31 st pair are furnished with these cirri, but only those anterior to them which are destitute of scales. Tail without elongated styles.

It is difficult to describe the colouring of this fine worm. Of specimens preserved in spirits the ground colour is a straw or ochre-yellow, but the back is clouded and spotted with dusky olive-green, there being a row of spots down the middle, a line or band along each side, and another row of spots exterior to this above the bases of the feet; and these markings correspond with the arrangement of the tubercles which roughen this surface. The number of segments is liable to vary. Audouin and Edwards say that there are 82 of them. In one specimen we found them to be about 80 ; but that which served for our figure, and which was twice the length of the other, had not less than 110.

Plate V. Fig. 1. P. scolopendrina of the natural size. 2. The head with its appendages, highly magnified; the front scales have been removed. 3. The proboscis laid open. 4. Section of a segment, showing the squamous feet; the scales have been raised and reverted. 5. A scale. 6. One of the cirrigerous feet. 7. A bristle of the dorsal brush. 8. The upper bristle of the ventral brush. 9. One of its under bristles.

6. Sigalion Boa, Johns.-Strangford Lough, Messrs. Hyndman and Thompson.

[To be continued.]

XXXVII.-On the Corymorpha nutans of Sars, a remarkable Hydroid Polype. By Edward Forbes, Esq., and Jorin Goodsin, Esq.

Ax the Birmingham Meeting of the British Association we gave a short account of a remarkable Hydroid Zoophyte, new to the British seas, which, supposing it to be altogether new, generically and specifically, we proposed to name Ellisia flos 
maris. This name was objected to by our distinguished friend Mr. Gray, as having been already employed to designate a genus of plants.

In a rare volume, written in the Norwegian language, entitled ' Beskivelser ag Jagttagelser af Polypernes, \&c., \&c.,' by M. Sars of Bergen, in Mr. Gray's possession, we recognised a figure and description of our animal, which had been previously discovered by $\mathbf{M}$. Sars, in the year 1835, and named by him Corymorpha nutans. The work of the Norwegian naturalist contains many most important observations on the marine animals of the west coast of Norway; and, from the intimate relations between the Fauna of that country and that of North Britain, deserves every attention from British naturalists. From having examined many of the animals described by $M$. Sars, we can bear witness to the accuracy and fulness of his descriptions. M. de Blainville had quoted the volume in question in the Appendix to his useful 'Manuel d'Actinologie,' and alluded to the genus Corymorpha, but has so mistaken the author's meaning that it was impossible to recognise the animal by the short description there given. Of course we withdraw altogether our proposed name of Ellisia, and adopt the original appellation of M. Sars.

As the animal is of great interest to the zoophytologist, being the largest Hydroid polype known, and throwing great light on the structure of its allies in the order Hydroideæ, and as we have had the most favourable opportunities of examining the creature in detail, having dredged more than twenty specimens and watched them alive,-while the discoverer of the species found but two, and those apparently from his notice thrown ashore in a debilitated state,-we have drawn up the following detailed account from the British examples, adding whatever appeared of additional interest from that of M. Sars.

The Corymorpha nutans is about four and a half inches in length, and its stem at the thickest part half an inch in diameter. In form it resembles a Tubularia rather than a Coryne; but not being placed in a strong horny tube like the former, presents much of the habit of the latter. When 
young the greater part of the body is inclosed in a thin brown membranous tube, which appears to have no organic connection with the animal, and which growing thinner as the animal gets older, at last disappears altogether. The body or stem is rounded, solid, and flexible, and is somewhat thicker towards the base than above, where it tapers rather suddenly to the neck. The base is fusiform and tapering to a point, and roots in the sand, fixing itself there by means of branching filamentous roots. When sand is much gathered round these roots, they present that subglobose appearance seen in M. Sars's figure. The whole of the stem is translucent, of a white colour tinged with pink, and lineated with pinkish-brown, longitudinal lines arranged in pairs. When magnified these lines are seen to be composed of oblong dots. M. Sars described these stripes as being of a pale vermilion colour in his specimens. These lines.do not run down the fusiform root, neither do they extend upwards quite to the neck, round which there is a band of pink. Above the neck is the head, which is ovate or pyriform, and terminates in a long pyramidal pink trunk, at the extremity of which is the mouth. Round the thickest part of the head is placed a row of between 40 and 50 tentacula, which are very long, white, and not contractile. They are not ciliated. Immediately above this circle of tentacula are the ovaries, which are 14 branched orange-coloured processes of considerable size, about one-third as long as the tentacula, each of their branches terminating in a sort of head. Above these the trunk is covered with very numerous white tentacula, directed upwards, not contractile, and very much shorter than those of the lower circle.

The internal structure is as follows. The stem is entirely solid, the substance filling it being jelly-like in appearance, as if contained in cells of a slightly fibrous tissue. When a transverse section of the stem is made in the living animal, the outer membrane contracts so as to diminish the dimensions of the amputated portion. No vascular structure could be detected, on the most minute examination of transverse and longitudinal sections of the stem; nor could any current be observed, either with the naked eye or the microscope, in 
this part of the living animal. The tentacula are all solid, and composed of the same substance as the stem and head. Within the head is the stomach, opening externally by a small circular mouth without any fringe or oral apparatus. 'This stomach is flask-shaped, having an elevated floor like the bottom of a bottle. It does not descend below the level of the lowermost range of tentacula. Its internal surface is villous, but not ciliated, neither are there any cilia on any part of the body.

This description of the internal structure differs from that of M. Sars, who says, "If the skin of the Polype, which is pretty strong, be cut up, the interior is found quite empty, without any intestines, except a small cylindrical gut or stomach, which at the upper end is a little wider than at the lower, and runs straight from the mouth downwards without bending to the lower half of the body, or a little lower, where it terminates abruptly, a large number of threads joined by network diverging like rays from its end towards the skin, where they fasten themselves. On this stomach are also to be seen strong longitudinal stripes." This appearance is presented only by the animal after having been kept for some time in alcohol; but we can assert positively that no such structure exists in the living animal. Misled by the above fallacious appearance, M. Sars has drawn a false analogy between it and the Actinece.

To what we have said of the deciduous tube, one of the most extraordinary points in the œconomy of this zoophyte, we must add that the filaments branching from the roots are, properly speaking, processes of its tube; for the young animal may be drawn out of its tube uninjured, and then the tube and the roots will be seen entire. In the adult animal the filaments and that part of its tube which envelopes the root still remain, while the upper part disappears. As ovaries of the specimen described by M. Sars were much further advanced than those in our examples, we quote the following observations from his account of them :-

"They are for the most part two-branched; at the end of the branches, the eggs, improperly so called, were seen resting, heaped together in large quantities. These eggs or buds 
have an exceedingly remarkable form and internal construction. For if they are examined with the microscope, it will be found that they have an oblong-round conformation, broadest at the top, and slightly blunted; smallest at the bottom and fastened by a very short stem to the branch. If considered still more attentively, it will be seen that these eggs (the internal structure is easily observed in consequence of their transparency,) seem already to contain within them the most important parts of the future polype. For instance, we observe in the middle a part which in form, \&c. corresponds to the knob in the full-grown animal. This part in the various eggs is of various forms; in the smaller ones, round or oblong; in the large and best developed, perfectly bottle-shaped. Further, there are observed in the upper or broad end of the egg four roundish projecting knots, which internally are continued as tubes downwards to the base of the bottle-shaped part. One of these knots is always larger and longer than the other three, which are alike, and it terminates after a small indentation with another small projecting knot. It therefore occurs to me as not improbable, that the largest knot, with its interior continuation, developes itself as the stem, while the interior bottle-shaped part forms the head of the polype. However much these eggs at the first glance resemble the egg capsules or fruit depositors in one kind of Sertularia, I was confirmed in the opinion just expressed, partly because I could not observe any eggs within them, but chiefly on account of another observation which appears to me important. In some of the larger eggs, where the above-mentioned internal parts were particularly plain, I observed very evident, indeed powerful movements; inasmuch as the egg, which seemed already to have reached its full maturity, alternately contracted and expanded itself quickly, and so by this systole and diastole endeavoured to disengage itself from the mother animal. I had no opportunity of observing the disengagement or the further development of it."

The language of the above observation is fanciful; but there can be no question of the accuracy of the statements.

We found the Corymorpha in 10-fathom water, in a sandy Ann. Nat. Hist. Vol. 5. No.32. July 1840. 
bottom in the Bay of Stromness, Orkney. When placed in a vessel of sea-water, it presented the appearance of a beautiful flower. Its head gracefully nodded (whence the appropriate specific appellation given it by Sars,) bending the upper part of its stem. It waved its long tentacula to and fro at pleasure, but seemed to have no power of contracting them. It could not be regarded as by any means an apathetic animal, and its beauty excited the admiration of all who saw it.

The following is the generic character given by Sars.

Gen. Совумоврна, nuv. Corpus longum, cylindricum, molle, superne clavato-vesiculosum, inferne conico-attenuatum, tubulo cutaceo hyalino tenuissimo partem corporis inferiorem circumdante, libere (non affixum) insidens. Clava conica, basi serie tentaculorum longorum circumdata, et ostentaculis brevibus sparsis.

1. Spec. Conymorpma nutans. Corpore hyalino, lineis longitudinalibus pallide rubris.

The affinities of this genus may be stated thus: The family of Tubulariada is a group of Hydroid polypes connecting the true Hydre with the Sertulariader. This connexion is twofold,-1st, between truly naked polypes and such as form a horny case; and 2nd, between polypes mostly simple or individual in their nature, and polypes truly compound. It is not too much then to expect, that the characters essentially generic in this family, should depend on this double progression from one alliance to another, as well as on some characteristic point in the organization of the animals comprising the group, considered as members of one family; in other words, on one positive and two comparative subjects of character.

The comparative characters we find,- -1 st, in the presence, absence, or nature of a tube, indicating a progression from the Hydra; and 2nd, in the form of the tube when present, whether simple or branched, indicating an approach to the Sertulariada.

The positive character we see in the arrangement of the tentacula surrounding the head, which arrangement is truly generic among the Tubulariade, and not merely a family character as in the preceding and succeeding families. Con- 
sistent with this view, we find accordingly that Coryne is distinguished by having scattered tentacula of one kind only, and by not possessing a tube; Hermione, by having scattered tentacula of one kind only, and a branched tube; Eudendrium, by having regular tentacula of one kind only, and a branched tube; Tubularia, by having two sets of regular tentacula, and a simple tube which is persistent; and Corymorpha, by having regular tentacula of two kinds, and a deciduous tube; the animal ultimately becoming naked.

Thus Corymorpha completes a circle linking Tubularia with Coryne, partaking of the characters of both. Yet as it partakes more of the nature of the former than of the latter, it is possible a genus as yet undiscovered may exist, characterized by presenting a permanently noticed body, and regular tentacula of one sort.

British specimens of the Corymorpha will be figured by Dr. Johnston in his Supplement to the 'History of British Zoophytes.'

XXXVIII.—Monograph of the Dorylidæ, a Family of the $\mathrm{Hy}-$ menoptera Heterogyna. By W. E. Shuckard, Esq.

[Concluded from p. 271.]

Sp. 2. Dorylus helvolus, Lin.

Length 121 lines.

Expansion $21 \frac{1}{2}$ lines.

Helvalus pilosus ; capite rufo, facie opalinâ convexâ, petiolo acetabuliformi segmento secundo multo minor.

Vespa helvola, Lin. Mus. Lud. Ulric. Reg. 412. 5.

Mutilla helvola, Lin. Syst. Nat. ed. 12". t. i. p. 2. 967. 8.

, Fab. Mant. i. 313. 18.

—_ , 'Der Kaper.' Christ. Naturgeschichte der Bienen, \&ac.

p. 151.

Dorylus helvolus, Fab. Ent. Syst. 2. 365. 1. Piez. 427. 1.

Coquebert, Dec. 2. pl. 16. fig. 1. sect. 4. 124. Dict. d'Hist. Nat. 2me Ed, 9. 555.

Reddish testaceous, very pilose, especially at the vertex, the thorax, the coxæ beneath, and the apex of the abdomen: the head (excepting the antennæ and the mandibles, which are bright castaneous,) red, sometimes obscure, with most frequently a strong opaline reflection; face about the anterior ocellus very prominent, depressed at the insertion of the antennæ, as also just behind and between their base, where it takes a triangular form: antennæ short, setaceous, the scape rather 